\title{
Water Resources Management In Support Of Raw Region Based On Decoupling Effect
}

\author{
Yu V Lesin ${ }^{1}$, E A Fedulova², A O Akulov ${ }^{2}$, S V Vik ${ }^{3}$, R L Korchagin ${ }^{2}$ \\ ${ }^{1}$ Yurga Technological Institute (branch) of Tomsk Polytechnic University \\ Leningradskaya 26, Yurga, Russian Federation, 652000 \\ ${ }^{2}$ Kemerovo state university \\ Krasnaya st. 6, Kemerovo, Russian Federation, 650043 \\ ${ }^{3}$ Kuzbass State Technical University named after T.F. Gorbachev \\ ul. Vesennyaya 28, Kemerovo, Russian Federation, 650043 \\ E-mail: akuanatolij@yandex.ru
}

\begin{abstract}
It determines the presence of the decoupling effect in the Russians raw regions materials by using water. Developed models that explain the relationship between the gross regional product and water intake. It proved no effect on the growth of water consumption in most regions of the reference commodity. Recommendations for the decoupling effect development in support of Russians raw regions.
\end{abstract}

\section{Introduction}

Rational water resources use and sufficiently complete waste water treatment - one of the key areas of sustainable development. The traditional type of economic development has led to the depletion of natural resources, environmental pollution, lack of clean water (Smith, 2003). It is important to the effective use water resources in the framework of the "green" sustainable development (Azad et al., 2015). The criterion of sustainable development is to use a minimum of resources to get the result unit (Bleischwitz, 2010). Only in this case it is possible to combine the growth and environmental requirements. Approach to water management must be differentiated according to the type of region. This takes into account parameters such as the current level of economic development, the load on the environment, the conditions of natural resources, strategic development. There are different approaches to the classification of regions (Stepanov, 2013; Zubarevich, 2012). In this study, we are interested in supporting raw materials regions. They are characterized by a significant proportion of the mining sector, the relatively high level of economic development, have a significant impact on the national economy of Russia as a whole.

Successful economic development of the raw regions was accompanied by increasing load on the environment. Water resources are scarce in most regions of the reference commodity. Extraction and processing of raw materials had a negative impact on water basin. The big problem is the contamination of drinking water (Dolnicar et al., 2012; Molinos-Senante et al., 2011). Therefore, you need to increase the efficiency of use of natural resources and the capacity of the biosphere. At present, the impact of economic growth in the regions supporting commodity on the environment is studied to a limited extent. Virtually no models to explain the dependence of environmental damage, in particular, water consumption and pollution, the economic dynamics. It is difficult to form a sound

\footnotetext{
(c) Content from this work may be used under the terms of the Creative Commons Attribution 3.0 licence. Any further distribution
} Published under licence by IOP Publishing Ltd 
environmental policy.

Sustainable development support raw regions achieved when decoupling effect. Decoupling means mismatch trends of various indicators, among which the previously assumed a close connection, for example, the growth and decline of developed and developing economies (Benjamin, 1992). In the modern environmental economics decoupling effect means a reduction in the environmental burden while maintaining or increasing the rate of economic growth. This effect is based on the more efficient use of natural resources, in particular water (Cahill, 1997). Achieving decoupling effect allows you to create a "green" economy, where growth in production does not lead to negative environmental consequences. Decoupling - the most attractive way of development for the country and individual regions. However, its existence is not currently shown. In fact, there are no empirical studies on the relationship between economic growth and environmental damage in the regions of Russia. In particular, we studied the effect of weak economic growth in the regions supporting commodities for consumption and water pollution. Thus, it is necessary to determine the relationship between economic growth and water consumption. This will allow predicting the damage to water resources and regulating water use in support of primary regions of Russia.

Thus, the purpose of the article - to identify the presence or absence of the effect of decoupling the use of water resources in support of primary regions of Russia, to develop a model that explains the impact of the economic growth in these regions on water consumption.

\section{Materials and Methods}

Polygon study are supporting commodity regions of the Russian Federation - Kemerovo region, Nenets Autonomous District, Komi Republic, Republic of Sakha, Sakhalin region, Tyumen region, the Khanty-Mansi Autonomous District, Yamalo-Nenets Autonomous District (of 8 subjects of the federation). These federated entities are classified as raw regions support in the official government records of the Russian Federation. The study period includes the years 2005-2014. The period of 10 years seems to be sufficient to produce statistically reliable estimates.

To conduct the study were used official statistical publications of the Federal Service of State Statistics (Rosstat of the Russian Federation), which presents the main indicators of economic development of all regions of the country. In particular, to determine the explanatory (independent) variable data on the production of gross regional product was used in support of primary regions (Table 1).

Table 1 - Production of gross regional product in support of primary regions of Russia, the index of physical volume, 2005-2014, per cent

\begin{tabular}{|l|c|c|c|c|c|c|c|c|c|c|c|}
\hline & 2005 & 2006 & 2007 & 2008 & 2009 & 2010 & 2011 & 2012 & 2013 & 2014 & $\begin{array}{c}\text { Growth } \\
\text { rate }\end{array}$ \\
\hline Kemerovo region & 106.8 & 107.2 & 106.8 & 102.1 & 92.9 & 102.7 & 102.3 & 95.8 & 96.0 & 102.1 & 114.4 \\
\hline $\begin{array}{l}\text { Nenets } \\
\text { Autonomous } \\
\text { District }\end{array}$ & 108.8 & 114.6 & 118.7 & 86.7 & 122.6 & 95.9 & 88.7 & 94.9 & 99.4 & 103.6 & 130.8 \\
\hline Komi Republic & 104.0 & 108.6 & 99.6 & 103.3 & 98.5 & 102.6 & 105.7 & 101.8 & 96.7 & 95.7 & 116.9 \\
\hline $\begin{array}{l}\text { Republic of } \\
\text { Sakha }\end{array}$ & 104.9 & 103.4 & 104.5 & 107.2 & 97.6 & 101.6 & 107.1 & 103.2 & 100.9 & 103.2 & 138.7 \\
\hline Sakhalin region & 108.8 & 112.2 & 126.3 & 95.7 & 110.9 & 108.0 & 104.3 & 97.5 & 101.4 & 100.7 & 172.6 \\
\hline Tyumen region & 110.8 & 106.0 & 103.1 & 103.8 & 94.3 & 106.0 & 103.1 & 99.8 & 102.4 & 98.1 & 129.9 \\
\hline $\begin{array}{l}\text { Khanty-Mansi } \\
\text { Autonomous } \\
\text { District }\end{array}$ & 112.4 & 106.7 & 103.2 & 102.9 & 95.2 & 103.0 & 100.9 & 98.1 & 100.0 & 98.7 & 122.0 \\
\hline $\begin{array}{l}\text { Yamalo-Nenets } \\
\text { Autonomous } \\
\text { District }\end{array}$ & 101.2 & 104.6 & 103.5 & 105.5 & 89.8 & 110.1 & 102.7 & 102.2 & 103.9 & 105.7 & 131.7 \\
\hline
\end{tabular}


Given the need for elimination of the effects of inflation and the inter-regional comparisons, the gross regional product is estimated on the basis of data on the index of the physical volume (in constant prices). The index of physical volume of the gross regional product is an integral feature of the economic development of the region as a whole. Since the reference commodity region's largest share in the production of gross value added of the industrial production, the index of physical volume of the gross regional product reflects the state of the relevant sectors of the economy.

As explanatory variables - characteristics of the water consumption in the region can be used indicators such as: water extraction; the use of fresh water; wastewater, transit, mine, mine waters; discharge of polluted wastewater, transit, mine, mine waters. The study used the indicator "water abstraction" because it best reflects the needs of the region's economy in water resources. Data on water intake in support of primary regions of Russia for the years 2005-2014 are presented in Table 2 .

Table 2 - Water intake in support of primary regions of Russia, sampling volume, 2005-2014, million cubic meters

\begin{tabular}{|l|c|c|c|c|c|c|c|c|c|c|c|}
\hline & 2005 & 2006 & 2007 & 2008 & 2009 & 2010 & 2011 & 2012 & 2013 & 2014 & $\begin{array}{c}\text { Growth } \\
\text { rate }\end{array}$ \\
\hline Kemerovo region & 2057 & 2098 & 2071 & 2102 & 2083 & 1751 & 2009 & 1992 & 1731 & 1726 & 0.84 \\
\hline $\begin{array}{l}\text { Nenets } \\
\text { Autonomous } \\
\text { District }\end{array}$ & 11 & 12 & 11 & 18 & 28 & 30 & 30 & 29 & 33 & 9 & 0.82 \\
\hline Komi Republic & 568 & 568 & 543 & 542 & 519 & 506 & 495 & 486 & 456 & 463 & 0.82 \\
\hline $\begin{array}{l}\text { Republic of } \\
\text { Sakha }\end{array}$ & 120 & 130 & 140 & 166 & 151 & 164 & 159 & 201 & 161 & 161 & 1.34 \\
\hline Sakhalin region & 295 & 306 & 300 & 263 & 256 & 263 & 223 & 249 & 194 & 162 & 0.55 \\
\hline Tyumen region & 1822 & 1929 & 1878 & 2095 & 1749 & 1825 & 2026 & 1980 & 2040 & 3022 & 1.66 \\
\hline $\begin{array}{l}\text { Khanty-Mansi } \\
\text { Autonomous } \\
\text { District }\end{array}$ & 1199 & 1340 & 1351 & 1560 & 1184 & 1185 & 1439 & 1388 & 1468 & 2411 & 2.01 \\
\hline $\begin{array}{l}\text { Yamalo-Nenets } \\
\text { Autonomous } \\
\text { District }\end{array}$ & 166 & 168 & 135 & 131 & 122 & 235 & 220 & 223 & 225 & 218 & 1.31 \\
\hline
\end{tabular}

As a basic research methods used in the calculation of the Pearson correlation coefficient of paired at the level of significance $\alpha=0.05$, build equations Simple Linear Regression to estimate the reliability parameters and criteria Student Fisher score determination, analysis of variance, analysis of the index. Along with these generally accepted statistical methods for grouping regions in terms of manifestations of decoupling it is proposed to use the metric $D_{e f}(1)$ :

$$
D_{e f}=G R P / W R
$$

where $G R P$ - the growth rate of the physical volume of the gross regional product over the period, per cent; $W R$ - the growth rate of consumption of water resources (water intake) for the same period, per cent.

The economic meaning of the metric is to demonstrate the correlation between economic growth and changes in water consumption. If it takes a value less than 1.00 , the water consumption is growing at a faster pace compared to the gross regional product (or decreases more slowly than the reduced gross regional product). If the metric is equal to 1.00 , the gross regional product and water consumption vary to the same extent. The value of the metric over 1.00 indicates a rapid increase in the gross regional product compared to water consumption and indirect evidence of the manifestation of the effect of decoupling.

Research procedure included the following steps.

1. Calculation of paired correlation coefficients Pearson to estimate the significance level $\alpha=0.05$ 
between the indices of "index of physical volume of gross regional product" and "withdrawals" assessment of the nature connection, the wording of the preliminary finding of the existence and nature of the statistical relationship between these indicators.

2. Calculation of the linear regression equations of the pair, where the independent variable used indicator "Index of physical volume of the gross regional product," explained variable - "water intake", the selection of the type of constraint equations, evaluation of reliability of the regression equation for the Fisher test, Student's t, explained variance (coefficient of determination).

3. Drawing conclusions about the nature of the relationship of indicators, identifying the presence or absence of a decoupling effect.

4. Develop a set of recommendations for rationalizing the use of water resources on the basis of the best available technologies.

\section{Results and Discussion}

Data on the correlation coefficients between the indicators' index of physical volume of gross regional product and withdrawals are presented in Table 3.

Table 3 - Correlation coefficients of indicators "index of physical volume of gross regional product" and "the volume of water intake" of support raw Russian regions

\begin{tabular}{|l|c|c|c|c|}
\hline & $\begin{array}{c}\text { The value of } \\
\text { the correlation } \\
\text { coefficient }\end{array}$ & $\begin{array}{c}\text { The number } \\
\text { degrees of } \\
\text { freedom }\end{array}$ & $\begin{array}{c}\text { The critical level } \\
\text { of the correlation } \\
\text { coefficient }\end{array}$ & $\begin{array}{c}\text { The character of the } \\
\text { statistical } \\
\text { relationship }\end{array}$ \\
\hline Kemerovo region & 0.2265 & 8 & 0.6319 & Absent \\
\hline $\begin{array}{l}\text { Nenets Autonomous } \\
\text { District }\end{array}$ & -0.4045 & 8 & 0.6319 & Absent \\
\hline Komi Republic & 0.6623 & 8 & 0.6319 & $\begin{array}{c}\text { Positive } \\
\text { relationship }\end{array}$ \\
\hline Republic of Sakha & -0.0529 & 8 & 0.6319 & Absent \\
\hline Sakhalin region & 0.5829 & 8 & 0.6319 & Absent \\
\hline Tyumen region & -0.3168 & 8 & 0.6319 & Absent \\
\hline $\begin{array}{l}\text { Khanty-Mansi } \\
\text { Autonomous District }\end{array}$ & -0.2908 & 8 & 0.6319 & Absent \\
\hline $\begin{array}{l}\text { Yamalo-Nenets } \\
\text { Autonomous District }\end{array}$ & 0.5329 & 8 & 0.6319 & Absent \\
\hline
\end{tabular}

The data in Table 3 show that a statistically significant positive correlation between economic growth and water intake observed in only one supporting the commodities of the Russian Federation of the eight (Komi Republic) regions. In other regions there is no statistically significant association, which indirectly indicates the existence of decoupling effect in the implementation of water. Economic growth has no rigid connection with the consumption of water. Thus, in seven of the eight regions, correlation coefficients are below a statistically significant level. However, their absolute values differ greatly from region to region. So, in the Sakhalin Region and the Yamalo-Nenets Autonomous District, the relationship between the index of gross regional product and water intake was positive and only a little not reached the level of statistical significance. In the Kemerovo region and the Republic of Sakha correlation coefficients are close to zero, indicating that the independent variables. In the Nenets, Khanty-Mansi Autonomous District, Tyumen region is also correlation coefficients below a critical level, but has a negative sign.

An analysis of correlation coefficients shows that certain manifestations of decoupling effects take place in seven of the eight regions. Increase water intake with an increase in the gross regional product is observed in only one region. At the same time in two other regions of the correlation between the index of physical volume of the gross regional product and water intake remains positive, but does not reach a statistically significant level. In five other regions there is no positive correlation, indicating a 
need for a thorough study the effect of decoupling on the basis of regression models. On the basis of data on production growth rate of the gross regional product and the water intake for the entire range studied regions (Figure 1) regression equation (2) was obtained.

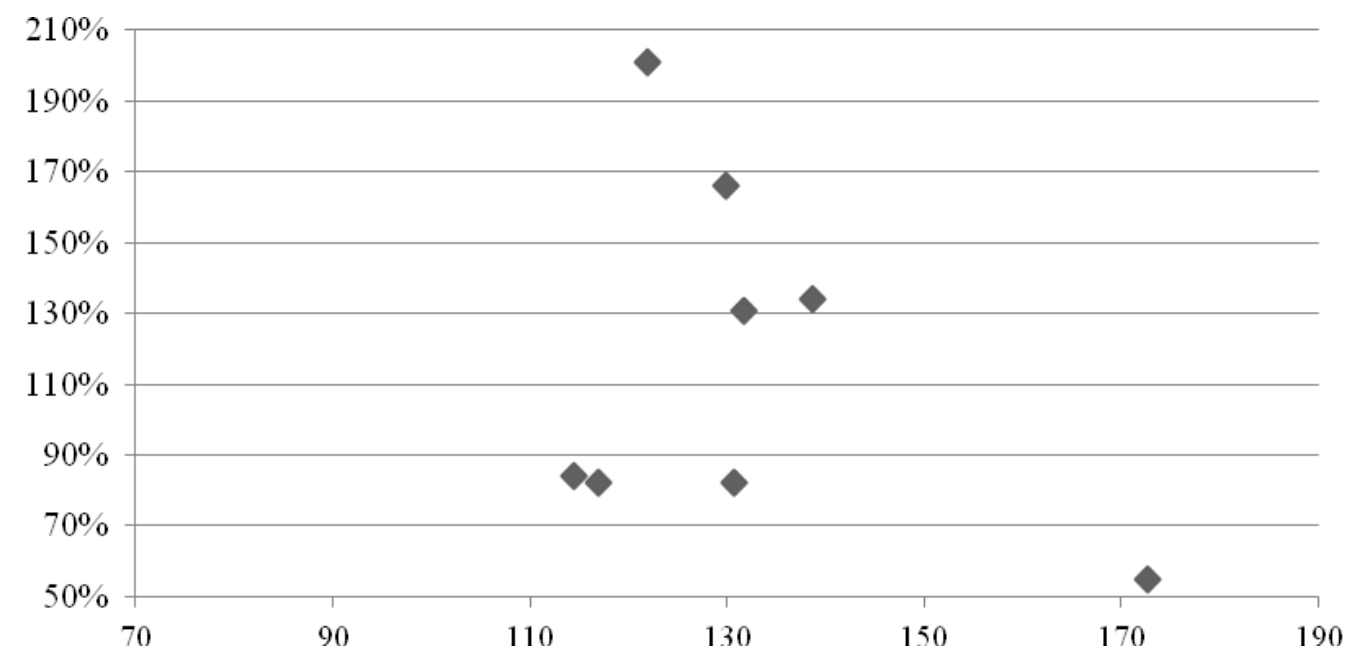

Figure 1 - Diagram of the scattering medium growth rate of gross regional product and water intake in support of primary regions of Russia, the average values for the period 2005-2014

As can be seen from Figure 1, the overall growth rate of the gross regional product is characterized by positive dynamics in all regions and a much smaller variation. The rate of growth of water intake during the period was a positive (in four regions out of eight), or negative.

The resulting regression equation is (2):

$$
Y=-0.94 X+2.41 \text {, }
$$

where $X$-index of physical volume of gross regional product, per cent; $Y$ - the volume of water abstraction, millions cubic meters.

At the same time, evaluation of the significance of the regression equation indicating its lack explanatory capacity (Table 4$)$.

Table 4 - Dispersion analysis of the regression equation (2)

\begin{tabular}{|l|c|c|c|c|}
\hline \multicolumn{1}{|c|}{ Source of variation } & $\begin{array}{c}\text { Sum of } \\
\text { squares }\end{array}$ & $\begin{array}{c}\text { The number degrees of } \\
\text { freedom }\end{array}$ & $\begin{array}{c}\text { Dispersion 1 degree of } \\
\text { freedom }\end{array}$ & $\begin{array}{c}F- \\
\text { statistics }\end{array}$ \\
\hline $\begin{array}{l}\text { Explained model } \\
\text { dispersion }\end{array}$ & 0.21 & 1 & 0.21 & 0.81 \\
\hline $\begin{array}{l}\text { The residual } \\
\text { dispersion }\end{array}$ & 1.53 & 6 & 0.26 & 1 \\
\hline The total dispersion & 1.73 & $8-1$ & & \\
\hline
\end{tabular}

As shown in Table 4, the equation (2) explains the small portion of the dispersion that does not allow its use for prediction. $T$-statistics (t-test) of 0.9 at a table value 2.447, $F$-statistics (Fisher's exact test) was 0.81 at the table 5.99. These values indicate a lack of statistical significance of the coefficients of the equation and forms of communication. Also it restricts the analytical and predictive capabilities of the equation (2) the high value of approximation errors $(34.75 \%)$. Consequently, the assessment of water intake depending on the dynamics of the gross regional product on the whole range of regions demonstrates a lack of statistical relationship. At the level of the reference commodity regions of Russia as a whole there was a mismatch trend of growth and water consumption. 
Consequently, in the period under decoupling trend, economic growth does not automatically lead to an increase in the need to use water. At the same time dynamics of these variables is almost independent of each other. Dynamics of consumption of water could "decouple" from the economic dynamics. But to reduce the need for water resources at the same time economic growth is not yet possible.

Analysis of individual regions to determine the features of display decoupling effect. The results of calculation of the metric (2) for the studied regions are shown in Figure 2.

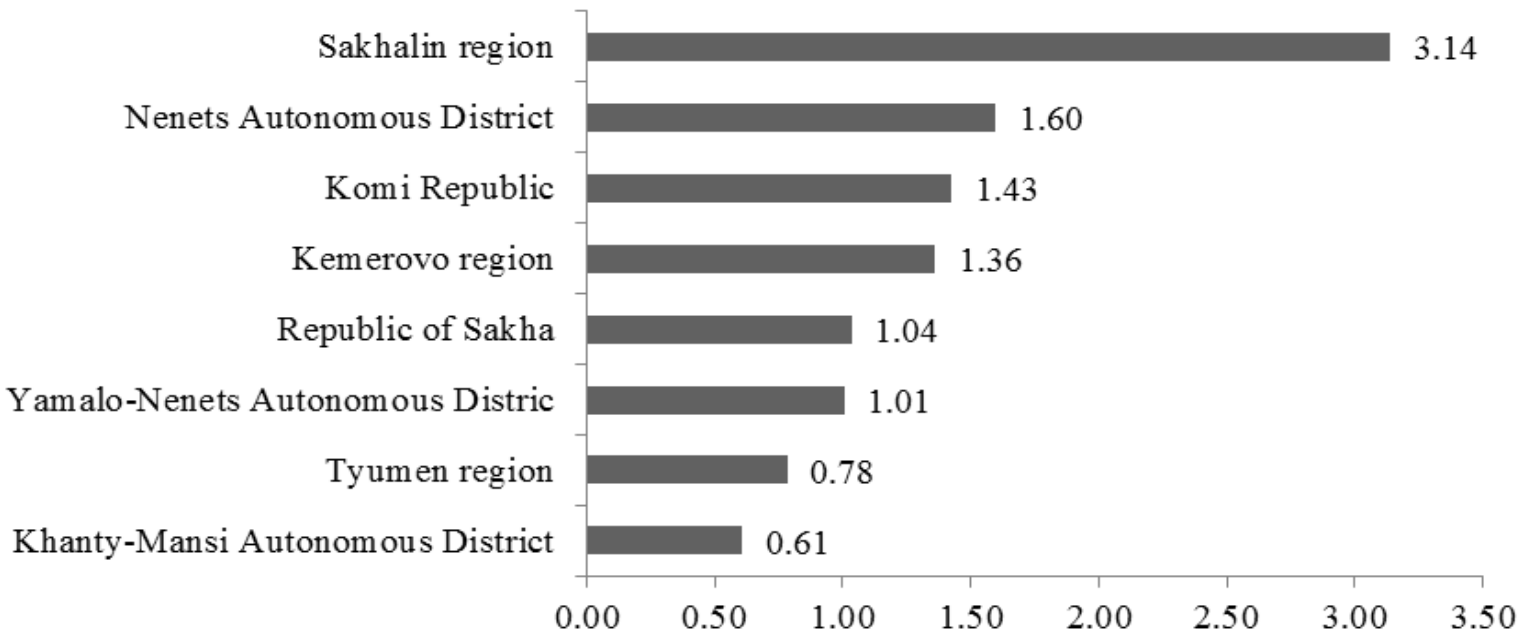

Figure 2 - The values of $D_{e f}$ metrics to support raw regions of Russia, 2005-2014

From the data in Figure 2 shows that the increase in water consumption outpaced the increase in gross regional product in only two regions - the Khanty-Mansiysk Autonomous District and the Tyumen region. The rest of the increase in demand for water lagged behind the growth of the gross regional product (from 1.01 to 1.60 times). Results of the analysis of correlation coefficients (Table 3) and Def metrics give different results in terms of the ratio of the rate of economic growth and changes in water consumption in the regions. This is due to the use in the first case of differentiated data, in the second - the period of integrated data.

Regression equations of the form (2) for each of the regions in question are shown in Table 5. The table shows that for all the studied regions, with the exception of the Republic of Komi, lacking both positive and negative relationship between economic growth and water intake.

As for the 10 observation periods critical Fisher criterion is 5.32, and the t-test -2.31 , seven of the eight regression equations presented in Table 5 are not statistically significant. This is also indicated low values of the coefficient of determination and the big error of approximation. Consequently, in the majority of regions of Russia of raw support economic growth did not lead to a corresponding increase in water consumption. At the same time formed decoupling effect has also been observed as a negative relationship between the change in the volume of gross regional product and water abstraction has been identified in the study.

For the Republic of Komi is characterized by a positive impact of economic growth on the consumption of water, one percent increase in the gross regional product growth causes the water needs of 6.6 million cubic meters. At the same time revealed the dependence explains only about $44 \%$ of the changes in water consumption. In all likelihood, you can expect a weakening of the statistical relationship and separation of the two trend lines, as is the case in other regions. 
Table 5 - Regression equations that determine the dependence of water abstraction from the dynamics of the physical volume of gross regional product in support of primary regions of Russia

\begin{tabular}{|l|c|c|c|c|c|}
\hline & Type the equation & $\begin{array}{c}F- \\
\text { test }\end{array}$ & $\begin{array}{c}T- \\
\text { test }\end{array}$ & $\begin{array}{c}\text { Error } \\
\text { approximation } \\
\text { percent }\end{array}$ & $\begin{array}{c}\text { The coefficient of } \\
\text { determination, } \\
\text { percent }\end{array}$ \\
\hline Kemerovo region & $Y=7.20 X+1231.71$ & 0.43 & 0.66 & 6.91 & 5.13 \\
\hline $\begin{array}{l}\text { Nenets Autonomous } \\
\text { District }\end{array}$ & $Y=-0.32 X+53.78$ & 1.25 & 1.56 & 48.32 & 16.36 \\
\hline Komi Republic & $Y=6.59 X-155.48$ & 6.25 & 2.50 & 5.04 & 43.86 \\
\hline Republic of Sakha & $Y=-0.41 X+197.70$ & 0.02 & 0.15 & 10.8 & 0.28 \\
\hline Sakhalin region & $Y=3.06 X-74.80$ & 4.12 & 2.03 & 13.7 & 33.98 \\
\hline Tyumen region & $Y=-25.11 X+4616.42$ & 0.89 & 0.94 & 8.54 & 10.04 \\
\hline $\begin{array}{l}\text { Khanty-Mansi } \\
\text { Autonomous District }\end{array}$ & $Y=-21.62 X+3659.76$ & 0.74 & 0.86 & 12.6 & 8.45 \\
\hline $\begin{array}{l}\text { Yamalo-Nenets } \\
\text { Autonomous District }\end{array}$ & $Y=4.55 X-283.66$ & 3.17 & 1.78 & 17.98 & 28.4 \\
\hline
\end{tabular}

\section{Practical Recommendations}

Study the relationship between water consumption and economic growth in the support of primary regions of Russia showed that in seven of the eight regions observed mismatch relevant trends. Economic growth ceased definitely lead to an increase in water consumption. A statistically significant association between these indicators, described by the equation of linear regression, preserved only in one region (Komi Republic). In other regions, there is no statistically significant relationship. In general, the range of the reference commodity regions proved no effect of economic growth to improve the flow of water. Therefore, in modeling the economic development of the region of the reference raw economic growth and use of water resources can be considered independent. Formation of system of indicators of development of the region may take account of the environmental load limitations are less (Fedulova et al., 2016).

These evaluation studies indicate that the growth of the gross regional product of the consumption of water does not change significantly. This can be viewed as a positive trend, which determines the beginning of the formation decoupling effect in support of primary regions of Russia. The further development of these regions and improving its sustainability requires further development of the decoupling effect. It is a negative relationship between economic growth and water consumption. In this case, a statistical study of the impact of economic growth on the use of water does not show lack of communication, and a significant negative relationship.

Formation pronounced decoupling effect requires a change in environmental policy. It is based must be put to the transition to the best available technology. With respect to existing businesses is necessary to carry out a gradual greening activities, modernization of technology and production, the introduction of modern technology for emissions and discharges clean. During the construction of the new commodity producers should ensure minimum environmental damage, to demand to achieve world-class environmental performance using best available techniques.

When the greening of existing enterprises must be based on planning, targets to reduce emissions and discharges into the environment by applying the best available technologies. Currently, commodity businesses do not have a clear objective to reduce water consumption and wastewater discharge. Existing limits clearly exceed the capacity of the environment and require adjustments. In determining the target water consumption values should focus on maximum environmental capacity of bearing raw regions. Strategic regional plans should take account of these constraints. In front of them should be given the task in the medium term to keep within the set limits. To do this within the framework of the investment programs should be provided for activities to transition to the best available technology to reduce environmental damage, with the assessment of the financial and 
economic impact and environmental performance. After the approval of the program at the level of the Commission, consisting of representatives of federal and regional authorities, businesses could qualify for tax breaks. This will give positive incentives to an active environmental policy. During the construction of new businesses should be required to use the best available technologies that should be a mandatory licensing requirement. Financial, technical and organizational capacity of the transition to the best available technology is limited. Therefore, the best available technology must be ranked in ecological efficiency. In particular, to reduce the discharge of waste water is most expedient to use biogidrobotanic cleaning method, active and passive treatment of wastewater discharge reduction technologies in the water.

To reduce the impact on the environment is necessary to change the terms of payment for environmental management, to expand the range of economic incentives. Currently, environmental fees and fines imposed by Rosprirodnadzor, are not tangible for violators. In this regard, it is necessary a significant increase in environmental sanctions, so that they have a real impact on natural resources. Today Rosprirodnadzor fines are negligible compared to the revenue and profit. Therefore, it is advisable to reconsider the approach to their establishment. It is proposed to levy fines in the amount of a certain percentage of the revenue of the coal enterprises, which make tangible punishment. Otherwise, nature will continue "as usual", with no systematic work to reduce environmental damage and without the use of best available technologies.

It is necessary to introduce a differentiated fee for a negative impact on the environment, taking into account regional specificities. The current level of differentiation is clearly insufficient; it requires corrections with the views of the authorities of the Federation, the expert community and the general public. For example, the coefficient taking into account the state of the water bodies of the Kemerovo region is only 1.16 - roughly the national average, and it is at an extremely high degree of water pollution. It seems that to establish the same rate for all federal district unreasonably regions. However, a radical increase in fees for use of natural resources alone cannot change the situation. To change it must be prepared to do commodity companies and enterprises. Undoubtedly, a reasonable regulation of fees for use of natural resources - a very complex issue, coupled with the collision of the plurality of interests. But gradually, gradually increase payments for the use of natural resources with the prospect of 5-10 years will create for nature predictable working conditions, will give an opportunity to plan environmental activities, long-term investments.

\section{Conclusions}

There is a need to change the environmental management system and environmental protection on the basis of the transfer of powers to the level of the Federation. According to Constitution of the Russian Federation, issues of ownership, use and disposal of natural resources and environmental management issues of environmental protection are in joint conducting the Russian Federation and its subjects. But in fact, the regions have the right to dispose of only subsoil, containing widespread mineral deposits. With regard to the subsoil with deposits of coal, oil and metals, the subjects of the Federation have not only the right of disposal of the joint, but even the right to use matching. Federal authorities, providing rights for subsoil use, come mainly from the fiscal interests.

It is therefore necessary for a redistribution of the functions of the federal center to the regions in terms of mineral resources and subsequent supervision of the mining companies. It is expedient to provide as a condition of admission to competitions in the field of subsurface distribution agreement with the Commission from the representatives of the authorities of the Federation. Such a commission could carry out the selection of nature and form requirements for their technical and environmental policies more carefully. It is also proposed to assign to sub-federal authorities, the right to apply to the authority which granted the license, with the obligatory consideration of the appeal on the merits at the optimum time. In this case it is possible, without waiting for the results of periodic monitoring; in case of complex environmental situation immediately appeal to the federal authority that issued the license, for the consideration of the merits. This practice exists in principle, but it is necessary to issue legally.

Supporting raw regions should be eligible to participate in the establishment of technical standards 
for emissions and emission limit values. They should vary from region to region and be based on the standards that exist for the best available techniques. Features of these regions with the very specific structure of the economy and at the same time severe environmental conditions require the differentiation of legal regulation of nature management and environmental protection. Environmental standards in such regions of the Federation should be more stringent nature - the more expensive, and the control system should increasingly focus on the regional level, than in the whole country. Implementation of these measures will reduce the adverse environmental impact of supporting raw regions form a background to the development of decoupling effect.

\section{References}

[1] Azad M, Ancev T \& Hernández-Sancho F. 2015, «Efficient Water Use for Sustainable Irrigation Industry», Water Resources Management, vol. 29, no. 5, pp. 1683-1696.

[2] Benjamin D. 1992, «Household composition, labour markets and labour demand: testing for separation in agricultural farm-household models», Econometrica, vol. 60, no 2, pp. 287322.

[3] Bleischwitz R. 2010, «International economics of resource productivity - Relevance, measurement, empirical trends, innovation, resource policies», International Economics and Economic Policy, vol. 7, pp. 227-244.

[4] Cahill S. 1997, «Calculating the rate of decoupling for crops under CAP/oilseeds reform», Journal of Agricultural Economics, vol. 48, no 3, pp. 349-378.

[5] Dolnicar S, Hurlimann A \& Grunn B 2012, «Water conservation behavior in Australia», Journal of Environmental Management, London, vol. 105, pp. 44-52.

[6] Fedulova E, Medvedev A, Kosinskiy P, Kononova S. \& Pobedash P. 2016. «Modeling of the agribusiness enterprise activity on the basis of the balanced scorecard», Foods and Raw Materials, vol. 4, no. 1, pp. 154-162.

[7] Molinos-Senante M, Hernández-Sancho F \& Sala-Garrido R. 2011, «Cost-benefit analysis of water-reuse projects for environmental purposes: A case study for Spanish wastewater treatment plants». Journal of Environmental Management, London, vol. 92, no. 12, pp. 3091-3097.

[8] Smith A 2003 «Transforming technological regimes for sustainable development: a role for appropriate technology niches?», Science and Public Policy, vol. 30, no. 2, pp. 127-135.

[9] Stepanov A 2013 «Classification of Russian regions by the degree of their orientation on external and internal markets», Regional Research of Russia, vol. 3, no. 4, pp. 324-327.

[10]Zubarevich N 2012 «Cities as the Centers for the Modernizatuin of the Economy and Human Capital», Sociological Research, no. 4, pp. 3-27. 